\title{
'Bound Coolies' and Other Indentured Workers in the Caribbean: Implications for debates about human trafficking and modern slavery
}

Kamala Kempadoo

\begin{abstract}
Under systems of indenture in the Caribbean, Europeans such as Irish, Scots and Portuguese, as well as Asians, primarily Indians, Chinese and Indonesians, were recruited, often under false pretences, and transported to the 'New World', where they were bound to an employer and the plantation in a state of interlocking incarceration'. Indentureship not only preceded, co-existed with, and survived slavery in the Caribbean, but was distinct in law and in practice from slavery. This article argues that the conditions of Caribbean indenture can be seen to be much more analogous to those represented in contemporary discussions about human trafficking and 'modern slavery' than those of slavery. Caribbean histories of indenture, it is proposed, can provide more appropriate conceptual tools for thinking about unfree labour today — whether state or privately sponsored — than the concept of slavery, given the parallels between this past migrant labour system in the Caribbean and those we witness and identify today as 'modern slavery' or human trafficking. This article thus urges a move away from the conflation of slavery and human trafficking with all forced, bonded and migrant labour, as is commonly the case, and for greater attention for historical evidence.
\end{abstract}

Keywords: indenture, transatlantic slavery, modern slavery, human trafficking, Caribbean

Please cite this article as: K Kempadoo, “Bound Coolies” and Other Indentured Workers in the Caribbean: Implications for debates about human trafficking and modern slavery', Anti-Trafficking Review, issue 9, 2017, pp. 48-63, www.antitraffickingreview.org

This is an open-access article distributed under the terms of the Creative Commons Attribution License (CC-BY). Under the CC-BY license, the public is free to share, adapt, and make commercial use of the work. Users must always give proper attribution to the authors and the Anti-Trafficking Review. 


\section{Introduction}

Practically, an immigrant is in the hands of the employer to whom he is bound. He cannot leave him; he cannot live without work; he can only get such work and on such terms as the employer chooses to set him; and all those necessities are enforced, not only by the inevitable influence of his isolated and dependent position, but by the terrors of imprisonment and the prospect of losing both labour and wages (Beaumont 1871). ${ }^{1}$

When it is remembered that the victim of the system-I can call them by no other name- - are generally simple, ignorant, illiterate, resourceless people belonging to the poorest class of this country and that they are induced to enter-or it would be more correct to say they are entrapped into entering-into these agreements by the unscrupulous representations of wily professional recruiters who are paid so much a head for the labour they supply and whose interest in them ceases the moment they are handed to the emigration agents, no fair minded man will, I think, hesitate to say the system is a monstrous system, iniquitous in itself, based on fraud and maintained by force (Gokhale 1912). ${ }^{2}$

Indian and Chinese indenture in the nineteenth century, as described by observers such as Gokhale and Beaumont, lend themselves to a reflection on that history for discussions about human trafficking today, given the striking similarities in conditions that are presented about both. The resurgence of the claim that Irish indentures were 'slaves' in the history of the Americas ${ }^{3}$ urges us to consider the broader question of how indentureship can be understood as 'modern slavery'.

1 J Beaumont, The New Slavery: An account of the Indian and Chinese immigrants in British Guiana, W Ridgway, London, 1871, republished by The Caribbean Press, 2011.

2 Gopal Krishna Gokhale's speech calling for suspension of Indian indentured emigration: Government of India, Legislative Department, Proceedings of the Council of Government, 1912.

3 See for example: L Hogan, L McAtackney and M C Reilly, 'The Unfree Irish in the Caribbean were Indentured Servants, Not Slaves', The Journal.ie, 6 October 2015, retrieved 10 April 2017, http://www.thejournal.ie/readme/irish-slaves-myth2369653-Oct2015. 
Given that Irish, Chinese and Indian indenture and the enslavement of Africans were important to the making of the Caribbean and have long been discussed by Caribbeanists, it seems appropriate to delve into the region's history and scholarship to think through such questions. I propose here that the simultaneous and serial histories of slavery and indentureship in the Caribbean, alongside centuries of observations, accounts, and analyses comparing the two systems, provide us with tools for a rethinking of current discourses of human trafficking and 'modern slavery'.

The questions I seek to engage here are not about which labour systemindentureship or slavery — was the more monstrous, for both were violent, coercive and inhumane. I am also not interested in contributing to scholarship that argues for a hierarchisation of oppression. Rather, I am preoccupied with questions about how histories of slavery and bound labour ${ }^{4}$ in areas of the world such as the Caribbean can be seen as 'parallel lives and intertwined belongings', which produce different knowledge and understandings, ${ }^{5}$ and which in turn could influence current thinking about human trafficking and 'modern slavery'. Moreover, as a critical sociologist, inspired by a historical materialist reading of the social and political, this paper does not engage with debates about the 'use and abuse' of history. Rather, it is an effort to present an alternative to those discourses on 'modern slavery' and human trafficking that lack a reflexivity about slavery in the past, and which currently dominate public and policy interpretations of forced and migrant labour. ${ }^{6}$

4 I use the term 'bound labour' to point generally to the practice of indenture in the Caribbean as well as contemporary migrant labour systems—state and privately sponsored-that recruit people often through fraudulent means, tie a labourer to an employer or sponsor, require them to work at a specific job for a period of time, and involve some form of financial indebtedness. This may or may not be similar to the concepts of 'bonded', 'debt-bonded' or 'forced labour'. It is noted, however, that these and other such terms all present definitional problems, generate endless debate amongst labour historians, and are often used interchangeably in discussions about human trafficking and modern slavery.

5 K Nimako, 'Conceptual Clarity Please! On the uses and abuses of the concepts of "slave" and "trade" in the study of the transatlantic slave trade and slavery' in M Araújo and S Rodríguez Maeso, Eurocentrism, Racism and Knowledge, Palgrave Macmillan, 2015, p. 189.

6 This paper was first presented at Durham University in May 2017, and while it has greatly benefitted from discussion with Siobhan McGrath, David Lambert, and Richard Huzzy, as well as from feedback from two anonymous reviewers and the Anti-Trafficking Review editors, it remains a work in progress. 


\section{Caribbean Indentureship}

Caribbeanist historians, sociologists, anthropologists, storytellers, novelists, poets and the like, tend to agree that indentureship was a labour system that pre-dated, co-existed with, and survived slavery, and was organised with a considerable level of fraud and violence by colonial governments to enable farm and plantation owners access to and control of a large pool of low-cost wage labourers for the agri-industry. Indentureship in the Caribbean was integral to the globalisation of capitalism from the fifteenth century onwards. The drive to accumulate capital not only interfered with other modes of production/ways of life and produced social and economic dislocations and political conflicts, but moved labour from those areas that it impoverished and disrupted to new hubs of production, such as plantations in the 'New World'. The Caribbean system of indenture relied on the recruitment, often under false pretences, of dispossessed and marginalised people (mostly young adult men) from Europe and Asia, and contractually binding them to a fixed term of work for a single employer in the British, Dutch, Danish, Spanish and French colonies in exchange for transportation to (and sometimes from) the colonies, subsistence wages and in some instances, land. Indenture contracts varied between one and fourteen years, with possibilities or requirements for re-indenture after the initial contract. The indentured were shipped to the Caribbean and confined to a plantation or estate where they lived and worked under conditions comparable to those for Africans under slavery. They had no choice in employer, could not change employers or buy themselves out of, or negotiate their contract, nor could they move freely without the consent of their employers. Planters in collusion with colonial governments often managed to maintain them in states of indenture or dependency through creating economic conditions that demanded or required re-indenture after the initial contract. The indentured were, in Guyanese Indian vernacular, 'bung coolies'-bound to employer and the plantation-in a pattern of 'interlocking incarceration'?

While most attention goes to the system that followed the abolition of slavery by the British in 1834, indentureship also occurred both before and during the period of slavery. Impoverished, destitute or imprisoned white European men and women, as well as children, made up some of the first cohorts of labourers from the late 1620 s to early 1700 s, the majority of whom were indentured to tobacco and cotton farms in the Caribbean. Numbers are hard to come by, but estimates are that prior to 1660 around 190,000 whites arrived in the English colonies in the Caribbean, such as Barbados, St. Kitts and Nevis, Montserrat, Antigua and

B V Lal, 'The Odyssey of Indenture: Fragmentation and reconstitution in the Indian diaspora', Diaspora, vol. 5, no. 2, 1996, p. 174. 
Jamaica. ${ }^{8}$ Barbados, for example, received a large number of Irish indentures and some Scots, English and Welsh who, prior to the late 1640s, are said to have mostly left for the Caribbean 'willingly', in search of a better life. Some were under contract 'to work for their master for an agreed-upon period (usually between three and seven years) in exchange for the cost of their passage, clothing, provisions while in service, and the promise of between two and ten acres of land upon the completion of their term of indenture'. Many thousands of others, including children, arrived without contracts. They were joined by vagrants, those considered felons and criminals who were exiled to the island, and political prisoners following conflicts such as the 1649 Cromwell invasion of Ireland, which led to several thousand Irish and others being 'Barbadosed'. ${ }^{10}$ Women were also rounded up and taken off the streets of London and shipped to the colonies. All were pressed into indenture as agricultural labourers, often working alongside enslaved Africans. ${ }^{11}$ With the expansion of the land-gobbling sugar plantation and the turn to Africa for a seemingly endless and more controlled labour supply, the promise of land as well as future work for the former indentured evaporated, leaving a mostly 'un(der)employed, poor and propertyless population'. ${ }^{12}$ White, landless, formerly indentured workers sought to re-indenture themselves, tried to migrate elsewhere, or eked out a living in the marginal spaces. ${ }^{13}$

8 M Binasco, 'The Activity of Irish Priests in the West Indies, 1638-1669', Irish Migration Studies in Latin America, vol. 7, no. 4, 2011, retrieved 10 April 2017, http:/ /www.irlandeses.org/imsla2011_7_04_10_Matteo_Binasco.htm.

9 M C Reilly, 'The Irish in Barbados: Labour, landscape and legacy' in A Donnell, M McGarrity and E O'Callaghan (eds.), Caribbean Irish Connections: Interdisciplinary perspectives, University of the West Indies Press, Kingston, 2015, p. 49.

10 J Sheppard, 'Indentured Servants of Barbados', Bim, vol. 15, no. 57, 1974, pp. 4155; S O'Callaghan, To Hell or Barbados? The ethnic cleansing of Ireland, Brandon, Dublin, 2001; J S Handler and M C Reilly, 'Contesting "White Slavery" in the Caribbean: Enslaved Africans and European indentured servants in seventeenth-century Barbados', New West Indian Guide, vol. 91, issue 1-21, 2017, pp 30-55.

11 Reilly; H Beckles, White Servitude and Black Slavery in Barbados, 1627-1715, University of Tennessee Press, Knoxville, 1989.

12 Reilly, p. 53. See also: D Lambert, White Creole Culture, Politics and Identity during the Age of Abolition, Cambridge University Press, Cambridge, 2005.

13 The ethnic group still known today as the 'Redlegs' - the poor whites of Barbados — are the legacy of this history. See also: H O'Brien, 'The Final Fortress: The Redlegs and Bajan-Irish Abjection' in A Donnell, M McGarrity and E O'Callaghan (eds.), Caribbean Irish Connections: Interdisciplinary perspectives, University of the West Indies Press, Kingston, 2015, pp. 174-186. 
Later cohorts of indentured workers arrived in the Caribbean from 1834, after the emancipation of Africans from slavery under the British, continuing well into the twentieth century, consisting primarily of Indians, Chinese and Indonesians ('Javanese'), with smaller numbers from Britain, Malta, France, Germany, and Madeira and the Azores ('Portuguese'). Some formerly enslaved Africans already in the Caribbean as well as Africans transported directly from Africa, were also indentured. Around half a million Indian workers replaced enslaved Africans on Caribbean plantations in this period with the majority in Guyana, Trinidad and Suriname, others in Jamaica, Guadeloupe, Grenada and French Guiana. ${ }^{14}$ Around 120,000 Chinese were transported to Cuba, and between 1853 and 1884 about 18,000 to British colonies, especially Guyana. ${ }^{15}$ Surinamese history captures the extent and diverse origins of the indentured population in the Caribbean from the nineteenth century on. The Dutch colony drew first on labour from China and Madeira, then from Dutch colonies in Indonesia and British colonies in the Caribbean, and from 1873 to 1916 from India. ${ }^{16}$ The transportation of indentured labourers from Indonesia continued until 1939.

Around the region, indentureship and slavery were complexly intertwined. The indentured all started out as agricultural workers and domestic servants, sometimes working alongside enslaved Africans. Yet some, such as whites and Chinese, were encouraged to take up semi-skilled, artisanal, or shopkeeping positions, with some whites securing racial privilege through the 'public and psychological' reward of whiteness ${ }^{17}$ taking up appointments as lowly managers and overseers of the enslaved. Some former enslaved Africans, in seeking to survive after being freed from slavery, opted for or were driven into indentureship, often moving to colonies where the agri-industry was then expanding (particularly the Guyanas) ${ }^{18}$

$14 \mathrm{~K}$ O Laurence, A Question of Labour: Indentured immigration into Trinidad and Guyana 1875-1917, Ian Randle Press, Kingston, 1994; L Roopnarine, 'A Critique of East Indian Indentured Historiography in the Caribbean', Labour History, vol. 55 no. 3, 2014, pp. 389-401.

15 M Turner, 'Chinese Contract Labor in Cuba, 1847-1874' in H Beckles and V Shepherd (eds.), Caribbean Freedom: Economy and society from Emancipation to the present, Ian Randle Press, Kingston, 1993, pp. 132-140; W Look Lai, Indentured Labor, Caribbean Sugar: Chinese and Indian migrants to the British West Indies, 1938-1918, Johns Hopkins University Press, Baltimore, 1993.

16 R Sewradj-Debipersad, Emancipatie van Hindoestaanse Vrouwen: Een beschrijving van veranderingen in het leven van Hindoestaanse vrounen in Suriname vanaf 1873 (The Emancipation of Hindustani Women: A description of changes in the lives of Hindustani women in Suriname from 1873), CERDES, Paramaribo, n.d.

17 Lambert, p.36.

18 See: Laurence 1994; M Schuller, 'African Immigration to French Guiana', Journal of African Studies Association of the West Indies, no. 4, 1971, pp. 62-73. 
In recalling the voyage of the Cinq-Freres with Africans from Sierra Leone to French Guiana in 1854, Monica Schuller observes that, 'Three shipping companies recruited indentured workers to French Guiana... the first two were for the voluntary engagement of free Africans, while the other involved the purchase of slaves followed by a declaration of their freedom, and their immediate enrolment as contract labour for French Guiana. ${ }^{19}$ Celine Flory adds to this, noting that the French government established a 'repurchasing' programme_rachat — whereby private merchants could purchase captive Africans and force them into a ten-year indenture contract in French Caribbean colonies. ${ }^{20}$ Such a switch from slavery to indenture also occurred when ships bound for Cuba and Brazil, carrying enslaved Africans in contravention to the European agreements of the time, were intercepted by British ships. The Africans were freed from slavery and, on arrival in the Caribbean, sold as indentured workers. ${ }^{21}$ Caribbean history is thus marked by the overlapping of two distinct labour regimes for over three centuries, with people sometimes moving between the two, experiencing both, and with planters managing both, at times simultaneously.

\section{Indentureship as Slavery?}

Caribbean indentureship — both the early and later forms — has often been compared to and described as slavery. In 1667, for example, the indentured were being described as 'poor men that are just permitted to live, and a very great part Irish, derided by the Negroes, and branded with the epithet "white slaves"' 22 , or as sharing a common sufferance and a common grievance with enslaved Africans. ${ }^{23}$ In 1835 in a petition to the Governor of Trinidad, Portuguese indentures wrote:

19 Schuller, p. 67.

20 C Flory, 'Between Indenture and Slavery? African indentured laborers in the French West Indies (1852-1862)', Francophone Africa: Critical perspectives, University of Portsmouth, 8 December 2016, retrieved 7 July 2017, http://francophone.port.ac.uk/ $? \mathrm{p}=1223$. In both Schuller's and Flory's work on the French Caribbean, indenture is synonymous with engagé labour.

21 E Williams, The History of the People of Trinidad and Tobago, Andre Deutsch, London, 1963.

22 Anonymous, quoted in Reilly, p. 51.

23 A Donnell, M McGarrity and E O'Callaghan, 'Introduction: Caribbean-Irish Connections: Creolizing histories, historicizing imaginings' in A Donnell, M McGarrity and E O'Callaghan (eds.), Caribbean Irish Connections, pp. 1-14. 
That with many of their countrymen, they were induced by certain evil disposed persons, under false pretenses, to quit their native country, Fayal, to become agricultural labourers in this Colony. Of the whole number thus cajoled, one third only are still in existence. The rest have fallen victims to the unhealthiness of the climate or the cruelties of the slavery system to which we, equally with the unfortunate blacks have been subjected. ...Men, women and children have suffered the greatest misery and oppression on several estates where they have been forced to work far beyond their strength by coercion of the whip, without proper shelter at night or adequate food during the day. ${ }^{24}$

Following the abolition of slavery, it was not uncommon for indentureship to be labelled 'the new slavery', especially by those agitating for the abolition of the system, with figures such as the former Chief Justice in British Guiana, Joseph Beaumont, publishing his observations in Britain under titles such as The New Slavery: An Account of the Indian and Chinese Immigrants in British Guiana. According to British abolitionist George Thompson in an address to the House of Commons in the 1880s about indentureship, 'The system of emigration has been false, and to attempt to carry it out extensively would only be to create a new slave trade under the false colours and a modified description. ${ }^{25}$ Similarly, a later trend in Caribbean historiography has been identified as 'neo-slave scholarship', in which indentured Indians in particular have been categorised and described in similar ways to enslaved Africans - as victims, forced and broken, and subject to intense violence, with little agency or ability to resist. ${ }^{26}$ Likewise, it is argued that the recent resurgence of the white slavery narrative in the Americas appropriates a history of suffering and trauma, and stresses 'a sense of shared victimization' with enslaved Africans. ${ }^{27}$

A large part of the claims of indenture-as-slavery lies in the material conditions of indentureship and de facto experiences of the enslaved and the indentured. Richard Ligon, in writing about his stay in Barbados from 1647 to 1650, remarked, if the masters be cruel, the servants have very wearisome and miserable lives...I have seen cruelty there done to Servants, as I did not think one Christian could

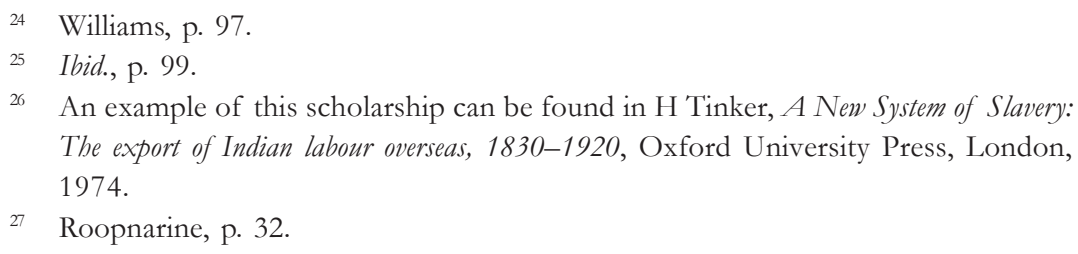


ANTI-TRAFFICKING REVIEW 9 (2017): 48-63

have done to another.' ${ }^{28}$ About the shipping of Chinese to the Caribbean, Mary

Turner notes:

The ships employed in the trade ... were prepared like the slave ships with gratings over the holds to allow only one person on deck at a time: small cannon, ready loaded, guarded the mouth of the hatches and the steam ships had neat contrivances for letting steam into the hold in case of real trouble ... only the chains were missing. Water shortages, disease and mutinies characterised the voyages... the sailors called them death voyages. ${ }^{29}$

On arrival in Cuba, Chinese indentures were 'subjected to the same discipline as slaves'.$^{30}$ Others have commented on the cultural similarities to the construction of the category 'slave', through a process of dehumanisation and violence. The British made 'coolies', Gaiutra Bahadur writes:

the system took gardeners, palanquin bearers, gold-smiths, cow-minders, leather-makers, boatmen, soldiers, and priests with centuries-old identities based on religion, kin and occupation and turned them all in an indistinguishable, degraded mass of plantation laborers without caste and family... Like the slaves before them, they were an entirely new people, forged by suffering, created through destruction. $^{31}$

Slavery and indenture appear to share many dimensions in such first- and secondhand accounts, and slavery has been and continues to be evoked in ways to speak about the cruelties, coercions, and highly exploitative character of the indentureship system. Such attempts to describe Caribbean indentureship as a new form of slavery, or to equate it with slavery-like conditions, are analogous to the twenty-first century efforts to make forms of migrant labour coeval with human trafficking. It also signals the ease with which slavery worked then, as it does today, as a metaphor for a lack of freedom. However, despite similarities in some conditions and experiences of enslavement and indenture and the violence of both labour systems in the Caribbean, the two are widely recognised by scholars and writers alike to be quite distinct from each other-distinctions that have resonance for discussions about 'modern slavery' and human trafficking.

28 Quoted in Reilly, p. 51.

29 Turner, p.136.

${ }^{30} \quad$ Ibid.

31 G Bahadur, Coolie Woman: The odyssey of indenture, University of Chicago Press, 2014, p. 63. 


\section{Modern Slavery and Human Trafficking as Indenture?}

A most obvious distinction is that the indentured in the Caribbean were for the most part contracted, and it was their labour that was sold and traded as a commodity through the indenture contract that tied them to the employer. They were not, as enslaved Africans were, legally defined as property, chattel, or non-human, not excluded from property rights, nor were their 'owners' compensated for the loss of property at the point of their emancipation. Morally and legally the indentured were defined as human persons — albeit, in Mill's term, sub-persons ${ }^{32}$ — who could make claims to legal rights both as citizens of their home country and under indenture laws in the colonies, ${ }^{33}$ and could own property. The premise of a contractde facto or de jure — and the claim to rights that were experienced by the indentured in the Caribbean, echo today throughout discussions about human trafficking and 'modern slavery', where it is also widely acknowledged that the majority of 'trafficked victims' or 'slaves' are defined as being bound to specific types and terms of work, often through a debt ${ }^{34}$ retain basic citizenship rights in their countries of origin and can make claims to a range of human rights, even while they may be denied rights as (im)migrants at the new sites of work.

Perhaps as importantly for a comparison with slavery discourses, is that indenture for the most part rested upon 'choice' - that is, impoverished, destitute, dispossessed people were compelled to find some form of subsistence and even though were 'lured' to the 'New World' by recruiters with promises of 'a new life' and prosperity without usually knowing about the cost of living in the colonies or the conditions of work, went voluntarily. ${ }^{35}$ The indentured, as is recounted for the Irish as well as later groups, had a choice between staying in places where conflict or famine ruled, or going along with a recruiter and accepting a contract to work for a fixed term overseas, at times being enticed by 'massive propaganda campaigns' about the opportunities in the Caribbean. ${ }^{36}$ Bahadur observes about the recruitment of Indian 'coolies':

32 C V Mills, 'The Political Economy of Personhood', Beyond Trafficking and Slavery, 16 June 2015, retrieved 27 April 2017, https://www.opendemocracy.net/ beyondslavery/charles-w-mills/political-economy-of-personhood.

33 Handler and Reilly; Roopnarine.

34 K Bales, Disposable People: New slavery in the global economy, University of California Press, Berkeley/Los Angeles, 1999; J Quirk, 'Trafficked into Slavery', Journal of Human Rights, vol. 6, no. 2, 2007, pp. 181-207.

35 Lal, p. 174.

36 Sheppard. 
ANTI-TRAFFICKING REVIEW 9 (2017): 48-63

Recruiters lived in the local imagination as schemers, liars, even kidnappers. According to widespread belief, they did not inform. They misinformed. They gave recruits the false impression that they could return home from their jobs for the weekend: they promised work as easy as sifting sugar; and they exaggerated the gains to be had, inflating wages and conjuring lands of milk, honey and gold. In coolie folk songs, the recruiter is a cursed, vilified figure. ${ }^{37}$

In such a process, it is argued, one can hardly speak of free choice, but instead a choice determined by need-a circumscribed agency. ${ }^{38}$ The 'choice' for indenture rested preponderantly on a desire to find a better life, often to escape violencefamily, spousal, and other—or starvation. Thus, as Dale Bisnauth concludes, even though the fear, in the case of Indians, of crossing 'the Black Waters' and hence to become outcasted, was very strong, 'the stress of circumstances' proved for some to be stronger. ${ }^{39}$ As with so-called modern slaves and trafficked persons today, they were, in Jo Doezema's words, 'forced to choose'. ${ }^{40}$ Enslaved Africans, on the other hand, had no semblance of choice at any point in the process. They were kidnapped, stolen from their homes and villages, manacled, and taken in chains from Africa to the Americas. There is little scholarly or other disagreement about their forced departure from villages in Africa, or about the brutal conditions in the baracoons and forts of West Africa, on the ships on the middle passage, or on the auction block and sugar plantations in the 'New World'. Enslavement did not depend on Africans being pushed by famine, landlessness, domestic violence, or other miserable conditions - they were captives, denied any form of decision-making or agency in the process of being made a slave.

Historiography thus identifies the 'root causes' for indenture as similar to those identified for trafficked persons and the 'modern slave'. The poverty, food shortages, landlessness, family circumstances, domestic violence, war or religious persecution, or a search for security and safety that propelled people into indenture, occurred alongside but was not the same as the history of the capture and enslavement of Africans. However, both systems shared a global context of the

37 Bahadur, p. 38

38 Sewradj-Debipersad. See also: Bahadur.

39 D Bisnauth, The Settlement of Indians in Guyana 1890-1930, Peepal Tree Press, London, 2000, p. 41; see also: Laurence.

40 J Doezema, 'Forced to Choose: Beyond the voluntary v. forced prostitution dichotomy' in K Kempadoo and J Doezema, Global Sex Workers: Rights, resistance and redefinition, Routledge, New York, 1998, pp. 34-50. 
expansion of capitalist production and industries and capital's constant search for cheap labour and services, as well as the space of the plantations in the 'New World'. And it is the parallel history of indenture, with its tangle of dislocation, survival strategies, fraud, demands of capital, and hopes for a better life, that led many people to enter into formal and informal agreements with recruiters and employers. Contemporary migrant labour systems, such as work programmes in Canada that rely on agricultural labour from Jamaica and Mexico, domestic labour from the Philippines, and sexual labour from Latin America and post-socialist states in Europe, continue to manifest problems similar to those encountered by indentured workers in Caribbean history: recruitment under false pretences, repayment through labour for an overseas passage, low wages, agreements that tie them to one employer, and poor working and living conditions at the new site of employment. And while human trafficking is usually claimed to operate underground, the state continues today to regulate labour and capital, profiting from arrangements that enable conditions of unfreedom. ${ }^{41}$ In this way, the role of the state in creating the conditions for trafficking resonates with the regulation of indenture by colonial governments.

Indenture was constructed as temporary and return home was promised and therefore sometimes possible. Between $20-25 \%$ of Asians are believed to have been repatriated after indenture in the Caribbean. Some were forced into another period of indenture in order to qualify for their passage home. Many of the migrant workers did not or would not return to their natal land once their indenture had ended, and having no other survival options, re-indentured themselves in the Caribbean. Others, once back in India, China or Java, re-indentured themselves and returned to the colonies. In researching her own family history, Bahadur notes, 'About 7 percent of emigrants arriving in Guiana in the dozen years before my great-grandmother did - 2,075 people - had been indentured before, either there or somewhere else. ${ }^{42}$ Analogous to situations of 're-trafficking' today, the re-indentured knew they were to pay off the costs for their transportation and maintenance through hard labour, that their movements would be circumscribed, and that the work and living conditions in their place of employment were harsh. Still, hope for a better life prevailed, directing them into the hands of unscrupulous middle-persons, recruiters, transporters and employers, with the expectation that the difficulties along the way were for a finite period. Today's experiences of seasonal migration for wage labour in salt pans, export fish-processing zones, strawberry farms, sex industries, domestic and care work or the kafala system, in

${ }^{41}$ The award-winning 2016 film 'Migrant Dreams' by Min Sook Lee, for example, carefully documents how some migrant farm workers in a small town in southern Canada deal with systemic oppression and exploitation from their brokers, employers and the Canadian state, http://www.migrantdreams.ca/.

42 Bahadur, p. 68. 
India, Denmark, the US, the Mekong, and the UAE, are most commonly held to represent the bulk of what is identified as human trafficking, forced labour and 'modern-slavery' in the twenty-first century. These exhibit similar qualities, with many people returning to or maintaining connections with home. ${ }^{43}$ Slavery, on the other hand, was for life and was hereditary, where the enslaved were 'alienated from all rights or claims of birth', ${ }^{44}$ and return to Africa was not an option. Few accounts of re-enslavement emerge in Caribbean history, and the concrete experience of moving from slavery into another form of unfree labour signals the distinction between the two systems. Even though plantation conditions might have been similar, there were clear boundaries between the conditions of indenture and those of slavery.

\section{Race, Gender and Sexuality}

Racialised and gendered dimensions of Caribbean indentureship can further elucidate analogies between historical and contemporary instantiations of migrant and forced labour. Caribbean history allows us to see that only certain racialised categories were deemed enslaveable (peoples who at the time were indigenous to the Americas and Africa), with blackness emerging as a critical category in the making of the 'slave' under modernity. The Caribbean indentureship experience however, was 'colour-blind'-notions of race were not foundational to the system, even while constructs of racial difference saturated indentureship and were used to justify the harsh treatment of some workers, and at times the privileging of others. The arguments that today 'modern slavery' and human trafficking do not depend on race again point to the similarities between contemporary forms of bound labour and those of yesteryear, while also serving to erase the specificity of contemporary global racialised divisions of labour. Conflating twenty-first century bound labour with slavery thus elides the significance of blackness in the making of transatlantic slavery, as well as the legacy of that anti-black racism that manifests today in the Americas through the incarceration and disenfranchisement of millions of people of African descent. It is also argued that such an erasure works politically to deny reparation claims for slavery. ${ }^{45}$ A paralleling of situations

43 See for example: Rhacel Salazar Parreñas, 'The Indenture of Migrant Domestic Workers', Women's Studies Quarterly, vol. 45, no. 1\&2, 2017, pp. 113-127. Her recent article employs the notion of indenture to describe the global conditions for Filipina migrant domestic workers who, she argues, are often classified and counted as 'trafficked victims' or 'modern slaves' by organisations such as Free the Slaves, the IOM, and the Walk Free Foundation.

44 J O'Connell Davidson, Modern Slavery: The margins of freedom, Palgrave McMillan, 2015, p. 45.

45 Handler and Reilly. 
described as human trafficking and 'modern slavery' with those of indenture could thus enhance our understandings about the ways in which race both informs and obscures labour relations under capitalism.

Women's sexuality also played a large part in recruitment processes for indenture. Accounts or analyses of indentured European women are hard to find, yet women were documented amongst the destitute, the landless, and the deported political or religious prisoners, even while details are scant. Jill Sheppard's research suggests that in 1645 soldiers in England visited 'brothels and other places of ill-repute and press-ganged 400 women of loose life to join several hundreds already on board ship for Barbados', although what became of the women is not apparent. ${ }^{46}$ From India and China historical evidence is more available. Women were deemed hard to recruit, and recruiters are recorded as having to pay up to double the amount for women than men. Moreover, Indian women were recruited not in the first place for their labour, but to tie men to the plantations-i.e. on the basis of their sexuality — to marry, provide care work, bring stability to the male labour force, and help eliminate the cost of remigration and the loss of workers. In India, 'Agents for indenture ... circulated notices in the Bihari countryside promising women that, if they migrated to the sugar colonies, they would "find husbands at once among the wealthier of their countrymen"" and in China, "prospective migrants to these colonies were given an incentive of 20 for wives', while 'women were not indentured but arrived officially as companions or wives of indentured Chinese men'. ${ }^{47}$ Women's (hetero)sexuality under indenture was of prime interest to the employers, although not for reproductive purposes - the plantocracy was not concerned with reproducing the labour force through encouraging births. Adult labour was plentiful, could be obtained cheaply, and was renewed through constant importation. ${ }^{48}$ In this way, sexual, emotional and care work for indentured Asian men was central to the women's recruitment and employment. As wage labourers they were deemed inferior to men, and were paid less even while they performed the same work in the fields, but their sexuality was highly prized by the employers. The sexualisation of, in particular, Asian indentured women, is not dissimilar to that which is described as 'sex trafficking' in the twenty-first century, in that sexual labour was, and is, an explicit part of the reasons for the recruitment and overseas employment of women. And as with the contemporary narrative, assertions of sexual agency by indentured Asian women located them in the view of the chroniclers of the time as 'immoral', 'loose' and prostitutes, leading planters at times to force women into monogamous unions. ${ }^{49}$ So too,

Sheppard, p. 49-50.

47 Bahadur, p. 36; Sheppard, p. 119. See also: Sewradj-Debipersad, p. 20.

48 P P Mohapatra, "Restoring the Family": Wife murders and the making of the sexual contract for Indian immigrant labour in the British Caribbean colonies, 1860-1920', Studies in History, vol. 11, issue 2, 1995, pp. 227-260.

49 Mohapatra; Bahadur. 
regulation of women's sexuality was heightened through narratives about the 'evils' of indentureship, reminiscent of the ways in which discourses of human trafficking work to curtail women's mobility and sexual agency.

\section{Conclusion}

While indenture was a vicious and highly exploitative system, relying on false promises to recruit workers, and confinement, abuse and violence at the site of employment, little in the narrating of Caribbean history conflates indenture and slavery, even while a rhetoric of slavery has at times been mobilised to evoke outrage and moral indignation about the conditions of indentureship. The legal status of the indentured as persons, the rights they held, the apparent choice they had to migrate and take up work in a new land, the possibilities or promise of return home, and the temporariness of their condition, all indicate that indenture was significantly different from slavery. Chroniclers of the time as well as historians and other writers have maintained distinct terms and identifications for what took place in the Caribbean from the seventeenth to the mid-twentieth centuries. Those who experienced the move from slavery into indentureship could also likely have spoken about corporeal, physical and economic differences.

Moreover, histories of the simultaneity of indentureship and slavery in the Caribbean enable us to pinpoint important distinctions between these labour systems, and suggest that labelling unfree or forced labour today as human trafficking or 'modern slavery' elides and obscures specificities and differences in legal status and conditions of work and life. As Julia O'Connell Davidson notes, 'Historical evidence ... underlines the dangers of de-contextualizing elements of human experience of relationships from entire bundles of rights, obligations, immunities and privileges that go with particular social statuses at particular moments in time. ${ }^{50}$ Even from this initial reading of a 'New World' past, indenture appears far more analogous to conditions of unfree labour today than transatlantic slavery, suggesting that it is a more useable and less salacious term than 'modern slavery' and its counterpart, human trafficking. Thus, rather than appealing to morality or fears about captivity through the notion of slavery or a discourse of human trafficking, we could seek to learn from the past as well as build strategies for change that perform critical analyses of everyday practice with care and respect for that past. In this regard, Caribbean history has much to offer to the contemporary debate. Nevertheless, this is not an argument to simply exchange terms. While a politics of indenture could deflate some of the hype and moral panic that comes with notions of 'modern slavery' and human trafficking, its adoption would not necessarily get 'to the bottom of things'. Migrant rights,

\footnotetext{
50 O’Connell Davidson, p. 69.
} 
labour rights, sex workers' rights and economic justice will continue to require our attention, if the goal is equality and safety for all.

Kamala Kempadoo is Professor in the Department of Social Science at York University in Toronto, Canada. She publishes and speaks widely on human trafficking and sex workers' rights from critical antiracist and transnational feminist perspectives. Her main publications include Global Sex Workers: Rights, resistance and redefinition (1998); Sun, Sex and Gold: Tourism and sex work in the Caribbean (1999); Sexing the Caribbean: Gender, race and sexual labor (2004), and Trafficking and Prostitution Reconsidered: New perspectives on migration, sex work and human rights (2005/ 2012). She is the 2017 recipient of the Distinguished Scientific Achievement Award of the Society for the Scientific Study of Sexuality. Email: kempadoo@yorku.ca 